\title{
Undermining the State? Informal Mining and Trajectories of State Formation in Eastern Mindanao, Philippines
}

\author{
Boris Verbrugge \\ Conflict Research Group, Ghent University, Belgium
}

\begin{abstract}
Building on critical perspectives on the state and the informal economy, this article provides an analysis of the "state of the state" on the eastern Mindanao mineral frontier. In the first instance, the author explains that the massive expansion of informal small-scale gold mining, instead of undermining state rule, has given rise to joint institutions of extraction that promote the interests of local politicians and informal miners, amongst others. Relying on the coercive and legitimizing strengths of local state institutions, local politicians have created an environment conducive to the persistence and arguably the further expansion of small-scale gold mining. In the process, they not only beef up their personal authority and the state's fiscal revenues, but also contribute to the consolidation of state rule on the upland frontier. Transcending the local level, this parallel process of smallscale mining expansion and state consolidation, the author argues, can be understood as the result of a long-standing tradition of decentralized state building through local strongmenpoliticians. Finally, attention is drawn to the expansion of large-scale mining and how it is highly likely to upset the sociopolitical stability built around joint extraction regimes in the informal small-scale mining economy.
\end{abstract}

Keywords: Philippines; Mindanao; artisanal and small-scale mining (ASM); state formation; informal economy

\section{Introduction}

In recent decades, small-scale gold mining in the Philippines has expanded on a massive scale. ${ }^{1}$ While accurate quantitative data are unavailable, not least due to pervasive informality in both the production and trade in gold, official gold sales to the Philippine central bank by small-scale miners nonetheless provide a good indication of this upward trend (Figure 1). In several years, official small-scale gold sales even surpassed the gross production value of large-scale metallic mining. After reaching an all-time high of 42.9 billion Philippine pesos (PHP) (around \$1 billion) in 2010, and despite historically high gold prices, by 2013 official gold sales had plummeted to a trifling PHP 0.3 billion (under $\$ 7$ million). ${ }^{2}$ Rather than reflecting a profound crisis in the small-scale mining (SSM) sector, this dramatic drop - according to countless key informants and numerous media reports - is first of all the result of new taxes on gold sales imposed in 2011 that have nurtured the growth of parallel, clandestine gold trading networks. While the export of

Correspondence Address: Boris Verbrugge, Conflict Research Group, Ghent University, Universiteitstraat 8, B-9000 Ghent, Belgium. Email: boris.verbrugge@ugent.be

${ }^{1}$ Note that I consistently use the term small-scale mining (SSM), the legal and popular term in the Philippines, rather than the internationally established term artisanal and small-scale mining (ASM).

${ }^{2}$ All dollars are US dollars unless otherwise noted. 


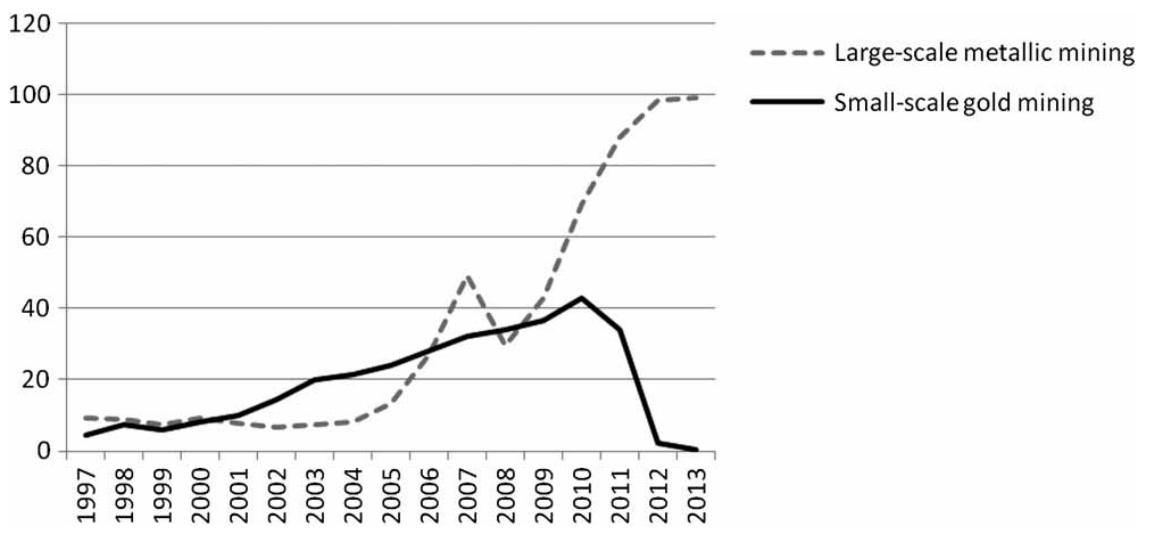

Figure 1. Gross production value in large-scale mining and small-scale mining, ${ }^{\mathrm{a}}$ in billion PHP $^{\mathrm{b}}$. Notes: ${ }^{a}$ Official gold sales to the central bank. ${ }^{b}$ One billion PHP equals approximately US\$25 million. Source: www.mgb.gov.ph.

SSM gold is prohibited by law (small-scale miners are legally bound to sell their gold to the central bank), unofficial estimates from traders and government officials suggest that a staggering 90 percent of small-scale gold production, while typically processed locally, is now smuggled to Hong Kong and then onwards to mainland China. ${ }^{3}$ In 2011, Hong Kong authorities recorded 81,192 kilograms of gold imported from the Philippines, while official Philippine export data (i.e., gold exported by large-scale mining companies) amounted to only 3 percent of this volume. Using the average 2011 gold price as our point of reference, ${ }^{4}$ illegal exports of SSM gold to Hong Kong alone were worth at least $\$ 4.5$ billion.

In addition to the unofficial trade in gold, at least in the eyes of the national government, the overwhelming majority of SSM operations are taking place "illegally," that is, outside government-designated SSM areas (Minahang Bayan). As I will discuss in Section 2, the existence of a sizeable "illegal" mining economy is usually treated as a harbinger of state weakness. Building on critical debates concerning the relationship between the informal (mining) economy and the state, I interrogate this proposition through an empirical inquiry into the anatomy of the local state on the small-scale gold mining frontier in Compostela Valley Province, on the southern island of Mindanao. ${ }^{5}$ I explain in Section 3 that the expansion of informal small-scale gold mining, rather than undermining state power, has paradoxically gone hand in hand with a consolidation of state rule at the local level. Rather than resulting from a deliberate top-down strategy on the part of a national state seeking to extend its fiscal-regulatory control over the "unruly uplands, " with the state: this engagement legitimizes and enforces "joint institutions of extraction" centered

\footnotetext{
${ }^{3}$ See, for example, Francisco 2012.

${ }^{4}$ In 2011 , the gold price averaged $\$ 1571$ per troy ounce, or approximately $\$ 55.40$ per gram. Data were retrieved from http://www.nma.org/pdf/gold/his_gold_prices.pdf (accessed 8 September 2014).

${ }^{5}$ The empirical material presented in this article was collected during eight months of field research in mining areas throughout the Philippines, with a particular focus on Compostela Valley Province. More than 200 open-ended interviews and many more informal discussions were conducted, with a prime focus on small-scale miners, upland settlers and local politicians.

${ }^{6} \mathrm{~S} c o t t 2009$.

${ }^{7}$ Snyder 2006.
} 
around protection services and the "informal formalization" otherwise volatile frontier setting. While local miner-politicians bank on small-scale mining as a source of rents and fiscal revenues and as a platform to assert their authority, a heterogeneous coalition of "capital interests" vested in the SSM sector simultaneously benefits from a regulatory environment conducive to the sector's survival and expansion.

In Section 4, this parallel process of SSM expansion and state consolidation is critically evaluated in the context of broader trajectories of state formation. In the first instance, I argue that the mutual entanglement between local state politics and the informal mining economy, epitomized by the joint institutions of extraction described in Section 3, should not be treated as a deformation of the Philippine state, but instead as an intricate product of a long-standing tradition of decentralized state building. In exchange for pacifying the frontier and for upholding the normative supremacy of democratic state rule, ${ }^{10}$ local elites enjoy a high degree of autonomy in the local political economy. ${ }^{11}$

Up to this point, my empirical account reads as a story of an advancing resource frontier that gradually becomes incorporated into the circuitries of the decentralized Philippine state. ${ }^{12}$ At the same time, however, Section 4 offers a timely reminder of the inherent volatility of resource frontiers that stand in continuous interaction with trends in global commodity markets. ${ }^{13}$ Specifically, rising global demand for minerals in recent years has sparked not only a new SSM boom, but also a renewed interest in eastern Mindanao on the part of large-scale mining companies. The extent and consequences of large-scale mining expansion remain to be seen, but initial observations suggest that it may portend a partial breakdown of joint institutions of extraction, with potentially grave consequences for sociopolitical stability.

\section{State Resilience and the Informal Mining Economy}

\subsection{The Persistence of Illegal Mining: A Harbinger of State Weakness?}

For academic observers working from different disciplinary backgrounds, the existence of a sizeable illegal mining sector poses particular challenges for state resilience. Fiscal sociologists for one would argue that the central state's inability to extract revenues from small-scale mining weakens its financial capacity and hence its ability to deliver vital public services, thus undermining its authority and legitimacy. ${ }^{14}$ As John Di John 2010 notes:

the extent to which the state monopolizes tax collection, the territorial reach of the revenue authority, tax levels, tax effort, the diversity of tax revenues and the manner in which tax is collected - all contribute to identifying the likelihood of state resilience. ${ }^{15}$

Other authors engaged in debates on the political economy/ecology of resource extraction suggest that the availability of lootable resources (resources that require minimal bureaucratic infrastructure to extract and tax $;^{16}$ ) provides ample opportunities for rent-seeking outside

\footnotetext{
${ }^{8}$ Benjaminsen and Lund 2003.

${ }^{9}$ Verbrugge 2014.

${ }^{10}$ Abinales 2000 and Wong 2006.

${ }^{11}$ Sidel 1999 and Lara and Schoofs 2013.

${ }^{12}$ This point was thoughtfully raised by one of the anonymous reviewers.

${ }^{13}$ Tsing 2003, 5101.

${ }^{14}$ Examples include Levi 1988, Bräutigam et al. 2008 and Larsson 2013.

${ }^{15}$ Di John 2010.

${ }^{16}$ Le Billon 2001.
} 
formal structures, which may in turn facilitate the formation of alternative power centers built around these resource rents. Examples may include warlord-politicians who cultivate their own patronage networks ${ }^{17}$ or secessionist rebel movements that explicitly seek to contest state power. ${ }^{18}$ Building on these observations, authors like Carolyn Nordstrom and Mark Duffield ${ }^{19}$ argue that the formation of what they describe as "shadow networks" or even "shadow states" has been facilitated by globalization, with increased global demand for illegal or even illicit goods, combined with the availability of a transnational structure for trading these goods, allowing local actors to bypass formal state structures and connect directly with transnational capital. Yet another defining characteristic of the shadows is the pervasive blurring of boundaries between formal-informal, legal-illegal and state-non-state: "While these networks are not comprised by states themselves," Nordstrom 2000 explains, "neither are they entirely distinct from, or opposite to, states - they work both through and around formal state representatives and institutions." 20 Nonetheless, given the authority and resources at their disposal, state actors often occupy key positions in shadow networks, but as rational actors seeking to maximize self-interest rather than as apologists of legal-bureaucratic state rule. In the long run, therefore, this self-interested instrumentalization of the state is likely to undermine the legitimacy and effectiveness of state institutions.

In this rather deterministic set of literature, ASM has come to occupy a prominent place. First, given their specific materiality, the alluvial mineral deposits of gold, diamonds and gems that ASM targets are highly lootable. ${ }^{21}$ Second, for geophysical reasons, ASM usually takes place in peripheral regions, where the presence of state institutions is a priori limited. ${ }^{22}$ Third, ASM camps are often depicted as violent and anarchic spaces, replete with uprooted young males prone to rebel against vested authorities. ${ }^{23}$

\subsection{Rethinking the Relationship Between State Formation and the Informal Economy}

This dominant interpretation of the illegal mining economy as a harbinger of state weakness has been criticized on a number of accounts. For one, authors like Linda Weiss and Kate Meagher have demonstrated that state institutions actually play a key role in facilitating long-term processes of "informalization," understood as an integral response of capitalism to a crisis of accumulation in the formal economy. ${ }^{24}$ More precisely, through ambiguous and inconsistent policies and lax law enforcement, states create both incentives and opportunities for employers to hire informal labor. Meanwhile, empirical studies of the state "from below" indicate a high degree of implicit or explicit support for informal economic activities by local state officials who are motivated by political (support from the huge number of people involved in the informal economy) and/or by personal (augmenting meager government wages) reasons. ${ }^{25}$ Local state officials are known to bank on the networks and authority vested in formal statehood to regulate

\footnotetext{
${ }^{17}$ Reno 1999.

${ }^{18}$ Collier and Hoeffler 2004 famously argued that rebellion in the post-cold war era is motivated by greed rather than grievance. This argument has been hotly debated and refined in the burgeoning literature on the "resource curse." For an overview of the existing evidence base, see Cuvelier et al. 2013.

${ }^{19}$ Duffield 2001, Nordstrom 2000, 2004; but see also Reno 1995, 1999.

${ }^{20}$ Nordstrom 2000, 36.

${ }^{21}$ Le Billon 2001.

${ }^{22}$ Fisher 2008.

${ }^{23}$ Le Billon 2008.

${ }^{24}$ Weiss 1987 and Meagher 1995.

${ }^{25}$ Rubbers 2007.
} 
access to - and shape the rules in - the informal economy and to cultivate clientelistic ties with informal economic actors. ${ }^{26}$

Richard Snyder, meanwhile, has developed an institutionalist critique of the literature on the "resource curse," drawing attention to the possible development of "joint institutions of extraction" that enable "cooperation between private and public actors who share income by exploiting resources." ${ }^{27}$ Joint extraction regimes would allow for the income from lootable resources to be used to "provide the revenue with which to govern and, thus, produce not disorder but stability." 28 In a similar vein, other authors have drawn attention to how economic self-interests vested in the informal economy might actually fit in with a broader elite pact geared toward the maintenance of sociopolitical stability. ${ }^{29}$

While the existence of unofficial ties between state officials and the informal economy is also recognized in the literature on the shadows (see Section 3.1), these authors share a critical but less essentialist and more empirically grounded approach toward the state. In recent years, this approach has been strengthened by a blossoming field of literature on "the anthropology of the state,"30 which aims to criticize and transcend established perspectives on the state as a fixed set of formal-legal institutions. Instead, state formation is approached as a fluid and dynamic process that involves a broad range of actors, both public and private, who draw upon the "idea of the state" 31 as an abstract and neutral source of political authority and as a legitimizing repertoire to underpin claims to public authority. Seen from this perspective, rather than being an inevitable distortion of legal-bureaucratic rationality, the reliance of state actors on the registers of state rule to extend control over the informal economy can, somewhat paradoxically, strengthen the "fantasy of the state" 32 as a unitary, objective and hierarchically organized institutional configuration.

Combining these critical approaches results in an understanding of the state as a dynamic institutional configuration with intricate ties to the informal economy. Such an understanding will form the analytical basis for the empirical analysis presented in the remainder of this article. In the first instance, I argue that at the local level, the interests of the state and those of actors in the purportedly informal mining economy have become intimately intertwined in joint institutions of extraction. This joint extraction regime at the local level is in turn embedded in a broader elite pact between local- and national-level political elites, with the former receiving a high degree of local political and economic autonomy in return for upholding sociopolitical stability and representing state rule on the frontier. Finally, I draw attention to the looming expansion of large-scale mining and how it risks upsetting not merely joint extraction regimes but the sociopolitical stability they generate as well.

\section{State Formation and Joint Extraction Regimes on the Informal Mining Frontier}

\subsection{Snapshots of Informal Mining in Compostela Valley}

Based on a combination of personal observations and estimates made by key informants, as of late 2012 the uplands of Compostela Valley Province were home to at least forty small-scale gold mining areas, employing tens if not hundreds of thousands of people. Aside from more

\footnotetext{
${ }^{26}$ Pattenden 2011.

${ }^{27}$ Snyder 2006, 948.

${ }^{28}$ Cuvelier et al. 2013, 962.

${ }^{29}$ Sherman 2003.

${ }^{30}$ Sharma and Gupta 2006, Eriksen 2011 and Vu 2010.

${ }^{31}$ Trouillot 2001 and Lund 2006.

${ }^{32}$ Hansen and Stepputat 2001.
} 


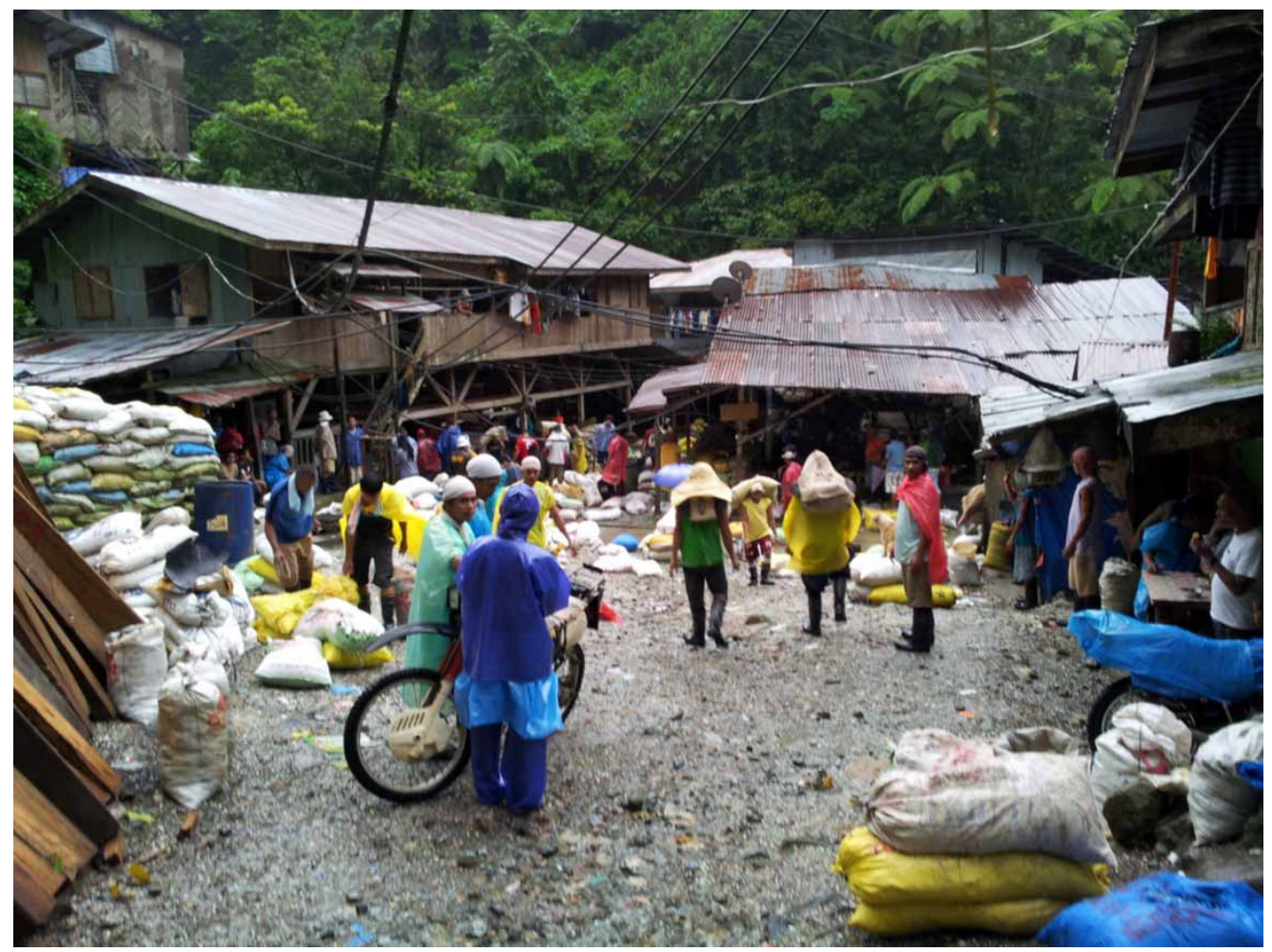

Figure 2. Labor force in front of a tunnel portal in the Diwalwal gold rush area, Monkayo municipality.

rudimentary panning and tunneling activities commonly associated with ASM, the province also boasts a high number of advanced SSM operations with higher degrees of capitalization. These involve pneumatic drills, explosives, mine trains, dump trucks, excavators and massive carbon-inpulp (CIP) processing plants. The output of these SSM operations consequently far exceeds that of "normal" ASM (Figures 2 and 3).

To be sure, a fairly elaborate formal regulatory system exists for small-scale gold mining, with Republic Act (RA) 7076 or the "people's small-scale mining law" of 1991 as its centerpiece. ${ }^{33}$ RA 7076 devolved authority over small-scale mining to Provincial/City Mining Regulatory Boards (P/CMRB) that are mandated to identify and legally recognize official SSM areas (Minahang Bayan) and to award two-year renewable SSM contracts to operators inside these areas. For various reasons, however, efforts to bring over small-scale mining into the state's regulatory fold through RA 7076 have so far proven unsuccessful. While an exhaustive review of the reasons underlying persistent informality is beyond the scope of this article, some observations are nonetheless appropriate here.

First, RA 7076 coexists uneasily with other legal mechanisms, and this gives rise to a complex regulatory environment marked by overlaps and inconsistencies. For example, while RA 7076 was supposed to replace the older and more permissive Presidential Decree (PD) 1899, local governments $^{34}$ have continued to use PD 1899 to award SSM permits. A recent government ruling

\footnotetext{
$\overline{{ }^{33} \text { Relevant laws and regulations can be consulted on the website of the Mines and Geosciences Bureau, see }}$ www.mgb.gov.ph.

${ }^{34}$ In descending order: region, province, municipality and barangay.
} 


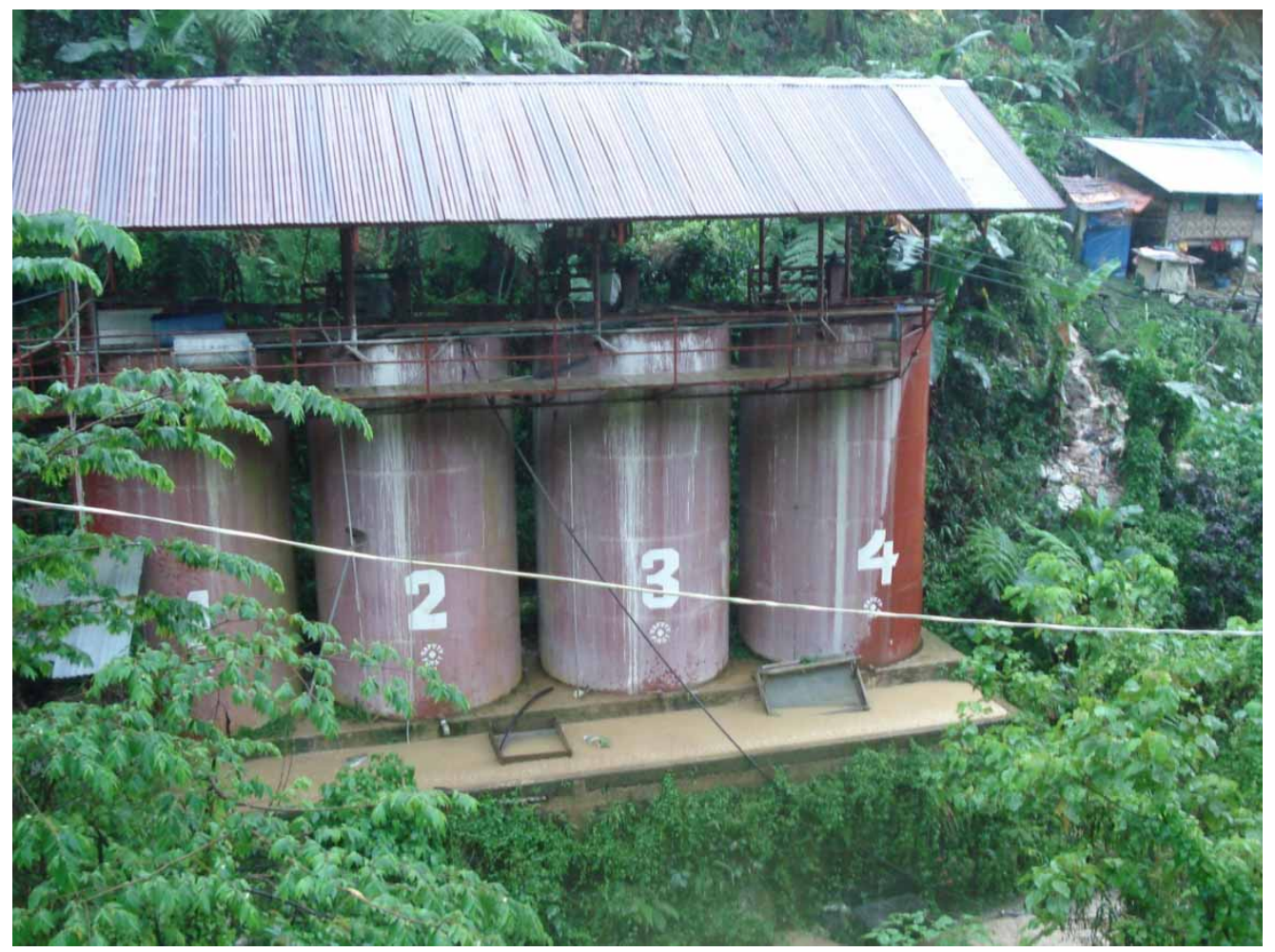

Figure 3. CIP processing plant, Diwalwal.

against the use of PD 1899 has pushed a significant number of SSM operations further into illegality. Second, national government agencies simply lack the capacity and resources to monitor SSM activities. Third, the permit process is plagued by a high fiscal-administrative burden, rampant rent-seeking and clientelism. While the $\mathrm{P} / \mathrm{CMRB}$ responsible for regulating smallscale mining are formally composed of different sectoral representatives, in practice they are often dominated by the local executive, with the mayor and the governor in particular retaining a high degree of discretion over the issuance of permits and the implementation of mining policies in the locality. ${ }^{35}$ Fourth, obtaining a permit requires the consent of existing surface rights holders. ${ }^{36}$ Increasingly, large tracts of land have been awarded to large-scale mining, whose owners have often been unwilling to grant legal approval for small-scale mining. In other areas, particularly those devoted to nature conservation, small-scale mining is simply prohibited.

Hence, critical questions can be raised regarding the government's commitment to formalizing and supporting small-scale mining. Yet, the national government seems to prefer large-scale, corporate mining, a point I discuss in depth in Section 4. In addition, official permits that are released are typically awarded to the financiers, landowners and/or tunnel owners, excluding the labor force at large. This raises important questions - which I do not address in this article - about who benefits from a labor force bereft of formal-legal recognition. Ultimately, and somewhat paradoxically, those who manage to negotiate their way

\footnotetext{
${ }^{35}$ Own observations, see also Jimeno 2009 and Wong et al. 2013.

${ }^{36}$ Usaid 2011.
} 
through the formal permit process are often those who no longer conform to the legal definition of small-scale mining.

\subsection{Stability and Friction on the Upland Frontier ${ }^{37}$}

The settlement of the wider Davao region ${ }^{38}$ and its gradual incorporation into the postcolonial body politic were intimately related to the extraction of the region's vast resources. ${ }^{39}$ Evidence (however scant) indicates that Compostela Valley was left largely untainted by the initial expansion of plantation-based agriculture under American colonial tutelage in the first half of the nineteenth century. This changed after Philippine independence in 1946, when settlers from the north of the country started arriving in the more remote "frontier regions" of Mindanao ${ }^{40}$ In tandem with the expansion of commercial logging, these settlers gradually moved into the uplands. These upland regions were home to indigenous tribes who - in parallel with processes elsewhere in Southeast $\mathrm{Asia}^{41}$ - retreated farther into the mountains after the initial incursions of migrant settlers. Although successive governments have tried to support the orderly settlement of Mindanao, migration to the upland frontier has been largely a spontaneous affair, taking place without government supervision. As a result, the uplands, most of which are owned by the state as public land, have witnessed a proliferation of illegal squatters. $^{42}$

While this process of upland migration sparked localized tensions between incoming settlers and indigenous inhabitants, in the immediate postwar decades the Davao frontier enjoyed a relatively high degree of sociopolitical stability. ${ }^{43}$ Until the 1970 s, land was still in ample supply, and existing upland settlers willingly vacated plots of land in return for compensation. Indeed, rather than being a question of dispossession, interviews with upland settlers suggest that the migrant influx led to an embryonic market for informal land claims, although the compensations newcomers offer were often ridiculously low. Furthermore, most in-migration followed a pattern of "chain migration," whereby "relatives, friends and village mates follow in the footsteps of the pioneer settlers." 44 As a result, nascent upland communities were often dominated by a few settler families that came from the same home region. As these settler families intermarried with each other and with the region's indigenous inhabitants, cross-cutting ties of kinship and solidarity began to emerge in upland communities. A final albeit crucial contributing factor to the stability of the Davao frontier, according to Patricio Abinales, was the role played by local strongmen-politicians, who relied on a combination of personal charisma, patronage, coercion and the legitimacy inherent to elected officialdom to pacify the locality, all the while acting as a liaison between Manila-based national elites and regional economic power brokers. I return to this point in detail in Section $4 .^{45}$

From the late 1960s onwards, however, several trends conspired to undermine frontier stability. One important factor was the gradual exhaustion of the land frontier, caused in part by the aggressive expansion of extractive industries (particularly plantation agriculture, commercial

\footnotetext{
${ }^{37}$ The following historical account is based primarily on interviews with local landowners and other key informants, including two anthropologists-historians. See also Abinales 2000 and Tiu 2005.

${ }^{38}$ Davao City is the major urban hub in eastern Mindanao.

${ }^{39}$ Abinales 2000 .

${ }^{40}$ Wernstedt and Simkins 1965.

${ }^{41}$ Scott 2009.

${ }^{42}$ Abinales 2000, 100-101.

${ }^{43}$ These observations build on a combination of own field research and Abinales 2000 .

${ }^{44}$ Umehara and Bautista 2004, 65.

${ }^{45}$ Abinales 2000; Wong 2006.
} 
logging and to a lesser extent corporate mining) under the control of national-level elites. ${ }^{46}$ Indeed, growing local tensions over land access coincided with a centralization of power in the hands of the martial law regime of dictator Ferdinand Marcos to the detriment of local strongmen-politicians who were no longer able to fulfill their role as frontier stabilizers. Instead, the regime increasingly came to rely on handpicked local allies and military might to maintain stability. In this increasingly polarized and repressive environment, the communist New People's Army (NPA) found fertile grounds for expansion, and by the early 1980s the uplands of eastern Mindanao had become one of the hotspots in the increasingly brutal war between the NPA and the Marcos regime. In this volatile environment, small-scale mining underwent a massive expansion.

\subsection{The Advancing Small-Scale Mining Frontier and the "Capital Interests",7}

By the 1960s migrant settlers (particularly Igorot from the northern Cordillera mountains) with prior experience in gold mining in their home region started panning for gold in the rivers and creeks of Compostela Valley. They were soon joined by other upland settlers who were facing difficulties in upland agriculture. Prior to the 1980s, small-scale gold mining had remained truly small-scale in nature. In the 1980s, however, the sector expanded notably. In large part, this expansion resulted from a crisis in capital-intensive corporate mining, caused by mounting political-economic instability and a crisis in international commodity markets. ${ }^{48}$ A growing number of unemployed, semi-skilled mine workers subsequently found their way into small-scale mining, initiating small tunneling activities throughout the region. In the decades that followed, some of these tunneling ventures underwent a process of capitalization initiated by a heterogeneous class of financiers that included lowland merchant-agricultural capitalists, a handful of local miners who had "struck it rich" and former employees in the higher echelons of corporate mining. Meanwhile, armed groups roaming the uplands started providing protection-cumextortion services to this nascent class of SSM entrepreneurs. Under the impetus of these "capital interests" and a seemingly inexhaustible supply of labor, small-scale gold mining steadily expanded.

In recent years, skyrocketing gold prices have given renewed impetus to the expansion of small-scale mining. This stimulated a further professionalization and capitalization of the sector, epitomized by a proliferation of sophisticated processing facilities, mining laboratories and medium-sized tunneling operations in increasingly remote upland areas. In this article, I focus on one particular factor that has supported, or at least facilitated, the advancement of the SSM frontier, namely, the progressive entanglement between the capital interests involved in small-scale mining, on the one hand, and local state actors, on the other.

\subsection{The Emergence of a Barangay-Centered Regulatory Order}

In order to better understand the process of state consolidation on the SSM frontier, let us consider the example of barangay Bukal in Nabunturan municipality. In the 1980s, amidst intensifying confrontations between the NPA and the Philippine constabulary, small-scale gold mining expanded in Bukal. Following the restoration of democracy at the local level in the late

\footnotetext{
${ }^{46}$ See, amongst others, Vitug 1993 and Abinales 2000; but their observations were confirmed by my own field research findings.

${ }^{47}$ For a more elaborate history of small-scale mining expansion in Compostela Valley, and the "capital interests" involved in it, see Verbrugge 2014.

${ }^{48}$ This argument has been further developed in another article submitted for peer review.
} 
1980s-early 1990s, prominent members of local settler families formed an alliance with former Davao del Norte provincial governor Prospero Amatong. In 1995 this alliance led to the creation of barangay Bukal. ${ }^{49}$ For various reasons, several respondents referred to Bukal as a "special barangay." For one, Bukal is located entirely on public land, and a significant part of its territory coincides with a protected landscape. Hence, the national government has so far failed to recognize human activity in the area, including the ubiquitous SSM activities. Notable exceptions include a large-scale mining permit issued to Aldevinco as well as a certificate of ancestral domain title (CADT) issued to a tribal association (Nasbatrico) under the 1997 Indigenous Peoples Rights Act (IPRA). The IPRA gives indigenous tribes priority rights over the mineral resources underlying their ancestral domain, ${ }^{50}$ but for reasons I cannot discuss at length here the tribal association lacks the capacity and legitimacy to wield these priority rights effectively. Instead its role is now confined to the collection of checkpoint fees, which I discuss in detail below. In addition, unlike other barangays, Bukal is not entitled to internal revenue allotments (IRA) from the national government, usually the number one source of local government revenues. Instead, it depends on a combination of yearly stipends from the province and municipality as well as locally raised revenues.

Following Bukal's establishment in 1995, barangay officials began registering informal land claims, land transfers and other economic activities. For this purpose, the barangay (through barangay ordinances) created several puroks, administrative subdivisions of the barangay. Over time, the barangay emerged as the key regulatory authority in the local economy and in informal land markets, and it became the first point of call in the case of land and other disputes. ${ }^{51}$ Only when the barangay captain fails to mediate effectively will a dispute be referred to the mayor, the formal judiciary or to national government agencies. Remarkably, in addition to land tenure regimes sanctioned by the national government, representatives of national government agencies and even local courts also tend to take into consideration existing informal settlement patterns at the barangay level.

The barangay's authority hinges on the support of local settler families. As elsewhere in the Philippines, politics in Bukal is a "family affair," 52 with the ruling coalition including a few prominent clans and families with representatives in local state institutions, the most important ones being the barangay council, the purok and the Civilian Volunteer Organization (CVO). Often referred to as the Tanod or barangay police, these purportedly unarmed CVOs play a vital role in keeping peace and order in the barangay, and they significantly beef up the barangay's coercive capacity. While the CVO operates at the behest of the barangay captain, many of its members come from local settler families. As one barangay official explained, "The CVO is controlling the area, and several of the landowners and barangay officials have trusted people in the CVO". ${ }^{33}$ In addition, at least in the case of Bukal, many of the CVOs have a history in the insurgency and are familiar not only with rebel tactics but in some cases with the guerillas themselves. ${ }^{54}$ Here another important function of the barangay comes into relief: the barangay as "frontline of the state" 55 in the ongoing conflict with the NPA. Asked about the security situation in the barangay, the barangay captain stated: "I negotiate with everyone, the army, the NPA ...". 56

\footnotetext{
${ }^{49}$ Interview with barangay officials, Bukal, October 2012.

${ }^{50}$ Usaid 2011.

${ }^{51}$ For additional evidence concerning the regulatory role of local politicians in informal land markets, see Gulane 2013.

${ }^{52}$ McCoy 1994.

${ }^{53}$ Interview with miner-landowner, Bukal, October 2012.

${ }^{54}$ Interview with barangay official, Nabunturan, February 2014; but see also Chap. 3 in Hedman and Sidel 2000 .

${ }^{55}$ Interview with barangay official, New Bataan, February 2014.

${ }^{56}$ Interview with barangay captain, Bukal, February 2012.
} 
Before proceeding to the regulatory dynamics in small-scale gold mining, two additional observations should be highlighted. These are crucial to understanding my argument. The first one is the blurring of boundaries between the capital interests in small-scale mining and politics at the local level. As in many other mining barangays, barangay officials in Bukal are themselves among the vested interests in small-scale mining, either directly as mining financiers or indirectly as landowners who receive royalties from small-scale mining. Taking part in electoral politics in the Philippines is a somewhat peculiar, informal and - according to most highly corrupt affair, with vote-buying being a defining feature of elections at all levels. In Bukal, as in other mining barangays, the price for a vote can go up to PHP 2000 (\$50). So what convinces miners to invest in politics? As Sidel explains, discretionary control over local state institutions in the Philippines entails privileged access to accumulation opportunities in the local economy. ${ }^{57}$ Indeed, barangay officials use their priority access to the state and its coercive machinery (the CVO) to protect and expand their own economic interests. Furthermore, they can use the state indirectly, as gatekeepers in the local economy, to solicit "contributions" from those who desire to invest locally. Finally, local politicians have access to broader, vertically organized political party networks that provide access to patronage from higher ranking politicians. ${ }^{58}$ As we will see below, however, this image of local politicians as rent-seekers is somewhat misleading, as it obscures an important degree of reciprocity in local politics.

The second important observation relates to the increased centrality of formal-legal authority in the exercise of public authority at the local level. While the barangay captain is typically a charismatic figure, the prestige of elected officialdom and social relations with higher ranking politicians are undoubtedly a boon for his personal authority. In this sense, the nascent barangay-centered regulatory order described above illustrates a broader process of state penetration, not necessarily as a fixed set of institutions but rather as a legitimizing repertoire based on the idea of legal-bureaucratic rationality as an abstract and universal source of power. Together, these two trends - the progressive entanglement between the local state and mining capital and the increased reliance on the "idea of the state" have enabled the emergence of "joint institutions of extraction" 60 centered around the "informal formalization" 61 of local tenure relations by local politicians.

\subsection{The Regulation of Informal Mining: From Brokerage to Informal Formalization}

Understanding the machinations of regulatory authority in small-scale gold mining areas necessitates a basic understanding of the process through which small-scale miners secure access to goldbearing land. Whenever small-scale miners want to explore or operate in a given area, they first need the consent of surface land claimants, who will typically receive a 10 percent royalty share. Where local self-financed miners or financiers are familiar with the landowner in question, said access can be negotiated directly. In other cases, financiers approach the barangay captain as the institutionalized representative of local landed interests and as the assumed pivot of local security arrangements. A barangay official then steps in and connects the financier with the landowner in question. In return, barangay officials solicit a range of "contributions" from financiers. In some cases, these donations are monetary in form; in other cases, local officials are granted the

\footnotetext{
${ }^{57}$ Sidel 1999.

${ }^{58}$ Landé 1968.

${ }^{59}$ Lund 2006.

${ }^{60}$ Snyder 2006.

${ }^{61}$ Benjaminsen and Lund 2003.
} 
"privilege" to operate a high-yielding tunnel (shifting). Since most financiers find it important to be on good terms with local officials in order to secure continued access to the area and to protect their investment, these donations tend to assume a recurrent character. They are particularly prominent in election periods, when rival politicians seek to woo financiers into beefing up their campaign funds. Here it is also important to mention that when a financier or landowner hits "highgrade," 62 he will often be confronted with a range of other armed rent-seekers, which may include army, police, CVOs, rebels and/or indistinct extortionist groups. While not wholly irrelevant for this account, a detailed inquiry into these other rent-seekers is not only difficult but would take us too far afield, as our main concern lies with understanding the role of local state officials in informal mining. Suffice to say that in many cases, armed rent-seekers develop a mutual understanding or at least a cohabitation arrangement with local state actors.

Over time, barangay officials have transcended - but not cast off - their role as brokers in the local economy. As gold mining operations expanded, they have developed sophisticated methods to extract rents from - and expand their regulatory control over - informal mining. In several of the mining barangays visited during my research, I found that the barangay is not just facilitating but is now actively registering and sanctioning agreements between financiers and landowners, particularly where it concerns bigger tunneling operations. After an oral agreement is reached between the respective parties, a written agreement is drafted by the purok or the barangay, specifying the parties involved, the revenue sharing modalities and the conditions of withdrawal. The registration of this agreement and the tunnel in question typically comes with a registration fee, which is but one example of a much broader range of fees the barangay, and increasingly also the municipality and province, are imposing on small-scale mining, gold buying and gold processing. After paying these fees, small-scale miners and landowners are issued with "official" receipts and a range of stamped documents, including community tax certificates, ${ }^{63}$ environmental permits, barangay- and municipal-clearances to operate in the area and business permits.

These fiscal-regulatory efforts in small-scale gold mining were given renewed impetus when a massive new gold rush enveloped Compostela Valley in the late 2000s. In ten "collection centers" (read: roadblocks) spread out over seven municipalities (Table 1), representatives from different local governments, together with tribal organizations in possession of a certificate of ancestral domain and in some cases also with SSM permittees, started taxing ore transport. In Bukal, two such checkpoints are located near the boundary with neighboring barangay Mainit. In one of these checkpoints, the barangay and municipality are collecting, respectively, PHP 300 (\$8) per dump truck and PHP 30 (\$0.80) per bag. In the other checkpoint, the Mansaka tribal association (Nasbatrico) is charging PHP 500 (\$12) per dump truck. Similar to the issuing of permits and clearances mentioned above, these payments invariably come with stamped receipts.

Accurate revenue data were difficult to collect at the barangay level, but barangay officials in Bukal explained that in addition to their own checkpoint revenues they are also entitled to municipal collections in excess of PHP 100,000 (\$2000) per year. ${ }^{64}$ The province of Compostela Valley, meanwhile, keeps detailed accounts of these "mining revenues," which are booked either as donations or as environmental user's fees (see Tables 1 and 2). In total, these revenues

\footnotetext{
${ }^{62}$ High-grade is a term that is very difficult to define. In short, it simply means a lot of gold in a short time span.

${ }^{63} \mathrm{~A}$ community tax certificate, or cedula, is the first requirement in order to qualify for any kind of permit or license or to conduct a business transaction in the barangay.

${ }^{64}$ Interview with barangay council member, Nabunturan, January 2014.
} 
Table 1. Comparative statement of mining fees, 2012.

Donations

Collection center

Tagnocon, Nabunturan

Camanlangan, New Bataan

Bugac, Mainit, Nabunturan

Golden Valley, Mabini

Ngan, Compostela

Mainit, Nabunturan

Mt. Diwalwal, Monkayo

New Leyte, Maco

Panoraon, Maco

Pamintaran, Maragusan

Total

Rates to be collected and start
P 10 (Aug. 2010)
P 10 (Sept. 2011)
P 5 (Nov. 2011)
P 5 (Nov. 2011)
P 5 (Sept. 2011)
P 5 (Dec. 2010)
N/A (May 2011)
N/A (May 2012)
N/A (May 2012)
P 15 (July 2009)

Source: Office of the Provincial Treasurer, Compostela Valley.

Table 2. Comparative statement of revenue collected from mining operations, updated with data available as of April 2013.

\begin{tabular}{|c|c|c|c|c|c|}
\hline & \multicolumn{5}{|c|}{ Calendar year } \\
\hline & 2008 & 2009 & 2010 & 2011 & 2012 \\
\hline Sand and gravel tax & P $2,052,168.48$ & P $2,535,159.97$ & P $2,431,745.26$ & P $2,269,868.26$ & P $2,740,493.70$ \\
\hline Small-scale mining & & & P $1,008,130.00$ & P $356,248.90$ & P $1,511,265.00$ \\
\hline Environmental user's fee & & & P $1,070,472.74$ & P $1,641,860.83$ & P $4,601,425.43$ \\
\hline Miscellaneous (donation) & & P $6,930,110.00$ & P $15,582,346.00$ & P $13,476,122.50$ & P $9,029,209.58$ \\
\hline Occupation fee & & & & P $236,715.00$ & P $129,570.00$ \\
\hline Excise tax & & & P $317,994.65$ & P 4,039,431.91 & P $2,620,839.00$ \\
\hline Total & P $2,052,168.48$ & P 9,465,269.97 & P $20,410,688.65$ & P $22,020,247.40$ & P $19,632,802.01$ \\
\hline
\end{tabular}

Source: Office of the Provincial Treasurer, Compostela Valley.

Note: The data displayed in Tables 1 and 2, as well as other additional information about these public revenues, were obtained with the kind permission of the provincial treasurer's office.
Environmental user's fee

P 3,238,991

P 4,978,504

\begin{tabular}{llll} 
& Rates to be collected & & Total \\
\cline { 2 - 3 } & P 5 35,780 & P 23,180 & P 58,960 \\
P 443,115 & P 5 & P 221,370 & P 664,485 \\
P 52,365 & P 5 & P 52,635 & P 105,000 \\
P 328,903 & P 5 & P 329,403 & P 658,306 \\
P 11,550 & P 5 & P 11,550 & P 23,100 \\
P 867,800 & P 5 & P 867,800 & P 1,735,600 \\
& P 5 & P 298,463.50 & P 298,463.50 \\
& P 5 & P 71,970 & P 71,970 \\
P 3,238,991 & P 5 & P 58,661 & P 58,661 \\
P 4,978,504 & P 5 & P 0 & P 3,238, 991
\end{tabular}


far outstrip the share of excise tax collected from formal small-scale and large-scale mining operations (see Table 2). In 2012, the province collected PHP 13.6 million (some \$340,000). While lower than in previous years, due to the devastating impact of typhoon Pablo, this amount - according to the provincial treasurer - still adds up to approximately 65 percent of fiscal revenues from mining and some 13 percent of locally raised revenues. At the same time, the significance of these revenues should not be exaggerated, as local governments continue to rely disproportionately on external resources, particularly the IRA, which accounts for about 80 percent of provincial income.

Examining these fiscal-regulatory efforts, several legal paradoxes emerge. To be sure, most of the interventions described above - even "donations" to local government - have a legal basis in the 1991 local government code, which defines the mandate of local government units in the era of decentralization. Furthermore, these regulatory interventions have gone hand in hand with a range of local government executive orders and ordinances aimed at "rationalizing" (as local government officials referred to it) small-scale mining. Meanwhile, the legal status of many if not most of the actual SSM operations remains unclear. For this reason, local politicians have supported the formation of SSM cooperatives throughout the province. These cooperatives subsequently applied for an official SSM permit, but for various reasons - prime among them the overlap with large-scale mining - most of these requests are still pending and the areas in question are now referred to as "proposed Minahang Bayan" (see Section 3.1). However, the formation of legally registered (with the Cooperative Development Authority) SSM cooperatives and the administrative trail left behind by these formalization attempts contribute to imbuing small-scale mining with at least a semblance of legality.

\subsection{Coercion, Legitimacy and Reciprocity in Joint Extraction Regimes}

Two fundamental and interrelated questions remain: Why do SSM financiers and landowners comply with paying these donations, permit fees and transport taxes? and Where does the money go? Initial clues with regard to the first question can be derived from the literature on the determinants of tax compliance, which argues that sustainable tax efforts hinge on a combination of coercion - the capacity of authorities to monitor and enforce compliance - and legitimacy. ${ }^{65}$ At the same time, local politics in the Philippines are often depicted as a coercive and in some cases even predatory affair, dominated by "local bosses" and warlord-politicians (see Section 4). ${ }^{66}$

The role of coercion in local politics should not be underestimated. When asked about the consequences of not paying transport fees, SSM financiers replied that their trucks could be confiscated by the provincial government or even by local officials of the DENR (a national government agency). Here it is also important to consider that Compostela Valley is home to armed groups that are all involved in some way in informal mining, usually in the form of protectioncum-extortion activities. Threats and actual acts of violence by these groups have targeted mining and processing equipment (which sometimes mysteriously "catches fire"), ore transport and in some cases even the physical integrity of financiers and/or their laborers. These armed groups sometimes cultivate indistinct ties with local politicians, giving rise to "peculiar coercive formations" (centered around local politicians and their private armies) that typically include people from all sorts of backgrounds, including (former) military, police and even rebels. ${ }^{67}$ Over time, CVOs have come to occupy a central position in these peculiar coercive formations.

\footnotetext{
${ }^{65}$ See, for example, Levi 1988 and Levi and Sacks 2009.

${ }^{66}$ Sidel 1999; Kreuzer 2009.

${ }^{67}$ Hedman and Sidel 2000, 58.
} 
They are often mobilized by barangay officials to protect their investment, as one landowner and former barangay captain explained: "The CVO is in control of the mining area, and no goons are allowed. Many of the CVOs are NPA returnees, some of them are also the relatives of landowners or barangay officials, and they are all locals." "68 In this opaque security environment, financiers are ever-wary of reprisal and, in Philippe Le Billon's words, "sustain their access to resources and protect their investments by paying 'whoever is in power'.,69

Meanwhile, the revenues extracted from informal mining go into the private coffers of politicians. Even leaving aside "contributions" from financiers to politicians, a significant discrepancy still exists between what the province claims as official checkpoint rates (PHP 10-15 per bag) and what financiers claim to be actually paying (PHP 30). Furthermore, politicians have a high degree of discretion over the expenditure of these local revenues, which usually end up in a "general fund" that serves as a patronage resource. ${ }^{70}$

While coercive and even predatory traits are evident in local politics in informal mining areas, my empirical analysis has revealed a significant degree of reciprocity between local politicians and the capital interests in small-scale mining. Snyder describes this reciprocal arrangement as "joint institutions of extraction" (see Section 2). ${ }^{71}$ On the one hand, local politicians devote money to interventions that indirectly benefit small-scale mine operators. Examples include the construction of roads connecting SSM areas to lowland areas (where most of the processing takes place) and the provision of basic services such as water and electricity. In addition, local politicians are in charge of maintaining the (supposedly voluntary) CVO, which provides at least some sense of security - however arbitrary - in mining areas.

More fundamentally, the broad range of fiscal-regulatory efforts described above seem to have led to a process of "informal formalization" 72 in local informal - at least from the eyes of the national government - tenure regimes. The wide array of "official" documents, agreements, permits and clearances, and associated fees and stamped receipts, all explicitly refer to statesanctioned legality as an abstract and universal source of legitimate authority. ${ }^{73}$ On the one hand, this process of informal formalization contributes to a broad acceptance of rent extraction by local state officials as something normal and mundane: "Everywhere we go we ask permission from the barangay. ... They ask fees and donations; they do their work; we do not complain."74 But informal formalization also benefits the capital interests involved in small-scale mining by imbuing local tenure regimes with a sense of predictability. For landowners, the registration and sanctioning of landowner-financier agreements by the barangay further consolidates their informal land claims and associated royalties. For financiers, compliance with these contributions, fees and donations should be understood as part of a broader strategy aimed at securing access to a high-value, geographically fixed resource in a frontier setting with an opaque security environment and, at first sight, indistinct surface tenure systems. This reciprocity between SSM interests and local politicians is reminiscent of Thomas Sikor and Christian Lund's observation about the recursive constitution of property and authority: "The process of recognition of claims as property simultaneously works to imbue the institution that provides such recognition with the recognition of its authority to do so. This is the "contract' that links property and authority.",75

\footnotetext{
${ }^{68}$ Interview, Bukal, October 2012.

${ }^{69}$ Le Billon 2001, 569.

${ }^{70}$ Interview Melvin Lamanilao, Revenue Watch Philippines, Davao City, February 2014.

${ }^{71}$ Snyder 2006.

${ }^{72}$ Benjaminsen and Lund 2003.

${ }^{73}$ Sharma and Gupta 2006.

${ }^{74}$ Interview with mining financier, Bukal, September 2012.

${ }^{75}$ Sikor and Lund 2009, 1.
} 


\section{Decentralized State Building and the Breakdown of Joint Extraction Regimes}

This section transcends the locality in an effort to understand how joint institutions of extraction on the informal mining frontier relate not only to the broader political economy of mining, but by extension also to broader trajectories of state formation in the Philippines. I argue that the existence of joint extraction regimes centered on the informal economy is not surprising when the long-standing tradition of decentralized state building in the Philippines is considered. I will also draw attention to how the recent expansion of large-scale mining is very likely to upset these institutional arrangements, with possibly profound consequences for sociopolitical stability.

\subsection{Decentralized State Building and Joint Extraction Regimes}

Despite a history of de jure centralization, in reality the Philippines has always been characterized by a high degree of decentralization. Already under American colonial rule - in the first half of the twentieth century - local- and provincial-level power brokers retained a high degree of autonomy in Manila, ${ }^{76}$ including discretionary control over the state's coercive machinery. ${ }^{77}$ This local autonomy persisted after independence, when local elites were absorbed by a nascent mass democracy built around political party networks that served primarily as mechanisms for the disbursement of patronage to local politicians, who in turn delivered local votes to their national counterparts. ${ }^{78}$ The Marcos regime (1972-1986) achieved some success in reining in selected local power brokers, but it did not overturn the localist basis of Philippine politics altogether. ${ }^{79}$ Instead, the local government code of 1991, which was presented as a radical move away from a historically rooted centralism and a response to the authoritarian excesses of martial law, ${ }^{80}$ was in fact a confirmation and arguably even a radicalization of this long-standing tradition of decentralized rule. ${ }^{81}$

According to John Sidel, this history of decentralized state building has given rise to a coercive form of local politics, with local "bosses" relying on discretionary control over local state institutions and the state's coercive apparatus to wield control in the local (informal) ${ }^{82}$ economy. ${ }^{83}$ With economic modernization, political-economic control began to rely on more sophisticated forms of regulation (e.g. zoning ordinances, licenses and franchises), with local politicians transforming themselves into brokers operating on behalf of landed interests and commercial capital. ${ }^{84}$ While these claims are partly in line with the empirical analysis presented in Section 3, attention has also been drawn to a degree of reciprocity in local politics built around joint institutions of extraction that serve the interests of both local politicians and local landowners and mining financiers. (To be sure, these two categories overlap.)

In this section, meanwhile, I draw attention to a second manifestation of reciprocity, namely that between local- and national-level elites. In the first instance, while local politicians derive personal wealth and fiscal revenues from informal small-scale mining, the Bangko Sentral (Philippine Central Bank) has long been buying SSM gold on a "no questions asked" basis. For decades, small-scale mining has been the number one source of national gold

\footnotetext{
${ }^{76}$ Hutchcroft 2000.

${ }^{77}$ Sidel 1999; Hedman and Sidel 2000, Chap. 3.

${ }^{78}$ Landé 1968.

${ }^{79}$ Hutchcroft 2000.

${ }^{80}$ On the Philippine experience of decentralization, see Eaton 2001.

${ }^{81}$ Hutchcroft 2000.

${ }^{82}$ Lara and Schoofs 2013.

${ }^{83}$ Sidel 1999 and Hedman and Sidel 2000.

${ }^{84}$ Sidel 1999.
} 
reserves, ${ }^{85}$ a fact that hints at the existence of joint institutions of extraction at the local and national levels. Approached from a different angle, and perhaps more fundamentally, reciprocity between local- and national-level elites resides in local politicians' contributions to sociopolitical stability and to state resilience on the upland frontier. ${ }^{86}$ First, local politicians use their authority and the resources at their disposal for local conflict resolution. ${ }^{87}$ More broadly, they contribute to "pacifying, confronting, co-opting and surrendering" forces that compete with the state - prime among which are the rebel movements. ${ }^{88}$ Second, local politicians' increased reliance on the fiscal-regulatory repertoire of the state to expand control over the informal mining economy which, in turn, strengthens their own authority - simultaneously contributes to a continual reproduction of the "idea of the state" 89 and to a broader acceptance of legal-bureaucratic rule in the "unruly uplands." 90 In short, the existence of joint institutions of extraction in the informal mining economy should be understood as a constitutive part of a broader elite pact that connects national elites with local politicians, with the latter fulfilling a key role in "sustaining the state's administrative reach and politico-military control." 91

\subsection{Large-scale Mining and the Destabilization of the Mineral Frontier?}

There are now important indications that sections of the national-level elite are now reneging on their side of this elite pact, leading to a breakdown of joint extraction regimes built around informal small-scale mining. First, the national government has seemingly given up on its share of SSM gold, obtained through official Bangko Sentral buying stations throughout the country. As noted in the introduction, in an effort to beef up the fiscal revenues from small-scale mining, in 2011 the Bureau of Internal Revenue (BIR) imposed a 5 percent withholding tax and a 2 percent excise tax on gold sales to the central bank. ${ }^{92}$ As a result, official gold sales declined by more than 90 percent and illegal trade in gold skyrocketed (Figure 1). Furthermore, Executive Order 79, which the government of Benigno Aquino (2010-) introduced in 2012 in an effort to rationalize the mining sector and attract more investment, contained several measures aimed at combatting illegal small-scale mining. ${ }^{93}$ In Sierra Leone, a similar disintegration of joint extraction regimes, in this case built around the country's abundant alluvial diamond wealth, contributed to a fiscal crisis, regime breakdown and eventually the country's descent into chaos. ${ }^{94}$ While it is unlikely that the elimination of small-scale mining's contribution to the national gold reserves would cause a fiscal crisis let alone regime breakdown in the Philippines, a second trend that is now becoming apparent is likely to generate substantial sociopolitical upheaval at the subnational level: the expansion of large-scale mining.

After the enactment of the 1995 Mining Act as the centerpiece of mineral resource governance in the Philippines, the national government, through the Mines and Geosciences Bureau, began issuing permits to large-scale mining companies for the exploration and development of the country's mineral reserves. As a result, as Figure 4 illustrates, most SSM areas in Compostela Valley

\footnotetext{
${ }^{85}$ Interview with anonymous respondent, Quezon City, March 2013.

${ }^{86}$ Abinales 2000 and Wong 2006.

${ }^{87}$ See also Adam and Verbrugge 2014.

${ }^{88}$ Wong 2006, 262.

${ }^{89}$ Lund 2006.

${ }^{90}$ Scott 2009.

${ }^{91}$ Lara and Schoofs 2013, 249.

${ }^{92}$ For background on this issue, see http://www.rappler.com/business/special-report/whymining/whymininglatest-stories/18717-bsp-s-9-mo-gold-purchases-from-small-miners-nosedive-94 (accessed 26 June 2014).

${ }^{93}$ For an analysis of executive order 79, see La Viña and De Leon 2012.

${ }^{94}$ Snyder 2006.
} 


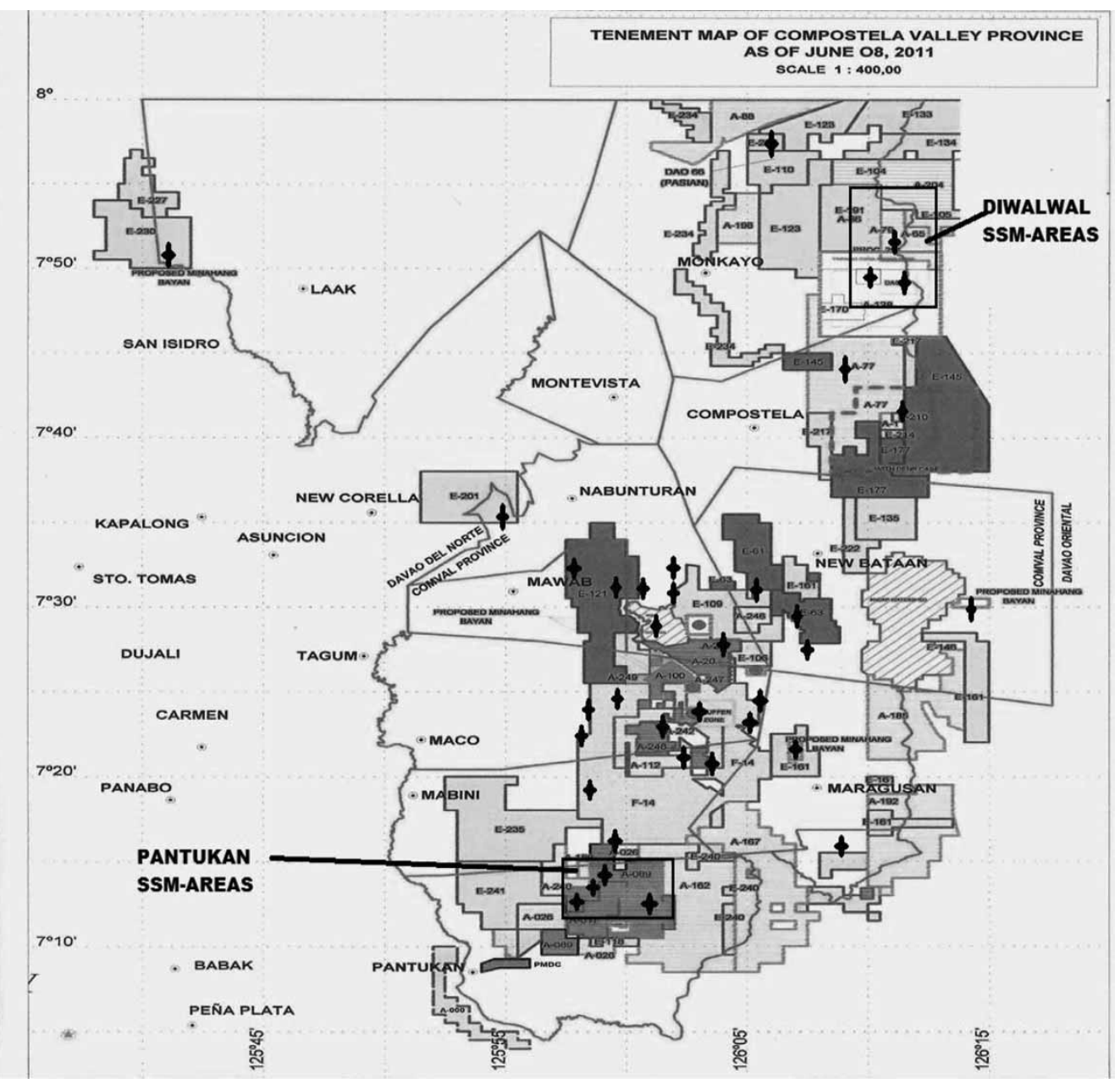

Figure 4. Location of small-scale mining areas.

Notes: The mining tenements map was provided by the Provincial Agricultural Office (PAGRO) of Compostela Valley (situation as of June 2011). On this map, I have attempted to indicate the location of SSM areas (black crosses) that were identified through personal observations and a map hanging in the barangay hall of Mt. Diwata, Monkayo municipality.

are now enveloped within large-scale mining concessions. Until very recently these companies' presence on the ground was limited. ${ }^{95}$ However, increased international (mainly Chinese) demand for gold, copper and other mineral resources in recent years has encouraged an intensification of exploration, and several companies are now making plans to move into the production phase. ${ }^{96}$ The expansion of large-scale mining is now the subject of heated debates involving civil society activists, academics and (mainly) left-leaning politicians alike, all blaming "the government" for supporting the mining sector with complete disregard for local populations. ${ }^{97}$ As I illustrated at

\footnotetext{
${ }^{95}$ APEX mining in Maco municipality is a notable expansion.

${ }^{96}$ On the recent Chinese incursions in the Philippine mining sector, see Wong et al. 2013.

${ }^{97}$ Holden 2005.
} 
length in Section 3, such a view obscures how local miner-politicians emboldened by decentralization $^{98}$ have emerged as the regulatory protégées of small-scale mining. In the remainder of this section, I illustrate how large-scale mining expansion and the associated proliferation of overlapping claims to mineral wealth, respectively, by small- and large-scale miners, is highly likely to upset sociopolitical stability by undermining joint extraction regimes at the local level.

In barangay Bukal, for one, Alsons Development and Investment Co., Inc., has been issued Mineral Production Sharing Agreement No. 094-97-XI. The company is using a multipronged strategy: handing out cease-and-desist orders issued by the Mines and Geosciences Bureau to small-scale miners and negotiating with barangay authorities to enable a smooth entry into the locality. So far, however, the company's presence on the ground is still in an embryonic stage. However, in other areas the entry of large-scale mining has led to rising tensions and even conflict. Rather than playing out simply between small- and large-scale mining operations, these conflicts typically involve indistinct and dynamic coalitions of politico-military actors that defy easy categorization in terms of state/non-state and in some cases even insurgency/counterinsurgency. However, in line with the analysis presented above, local would-be politicians occupy central positions in these coalitions.

The Diwalwal case in Monkayo municipality, in the north of the Compostela Valley Province, illustrates these claims. In the early 1980 s, small-scale gold mining activities, similar to those found elsewhere in the region, began to proliferate in the Diwalwal area. ${ }^{99}$ These activities underwent a gradual process of capitalization, with Sino-Filipino merchant capital in particular investing in the further development of tunneling and processing activities, enabling much higher levels of output. This capitalization went hand in hand with the creation of indistinct cartels between these mining financiers as well as army commanders, police officers, and communist and Muslim rebels. In time these groups became embroiled in violent conflicts over underground ore bodies. In line with events in Bukal, the situation stabilized somewhat in the 1990s, according to local miners, mainly because of the interventions of barangay authorities, under the leadership of charismatic barangay captain Franco Tito and his "peace guards," as small-scale miners once euphemistically called the CVOs. Whenever a conflict emerged between different tunnel owners, barangay authorities would intervene to restore order.

This stability the barangay-centered regulatory order provided was upset in the late 1990s, when Semco, a domestic subsidiary of Canadian Marcopper Mining, entered the scene. Rather than attempting to wrest control away from existing miners, Semco opted instead to enter into a murky legal arrangement with JB Mining, one of the major SSM groups operating in Diwalwal. Beefed up by its association with Semco, JB Mining began to (literally) undermine its competitors, and this led to a renewed escalation of the dirty underground war: this time pitting informal, small-scale miners - many of whom no longer qualified as small scale given their level of capitalization - against JB Mining, which now operated in the twilight between informal and formal medium-scale mining. ${ }^{100}$ The conflict soon spilled over into the political arena: while barangay authorities were widely presumed to be catering to the interests of small-scale miners, municipal politics were dominated by the Brilliantes family, which was in charge of JB Mining. Municipal mayor Joel Brilliantes used his mayoral prerogatives and his connections inside the army as a former military intelligence officer to harass his informal mining foes both legally and physically.

\footnotetext{
${ }^{98}$ Of particular relevance here are the Local Government Code of 1991, the Small-Scale Mining Act of 1991 and the Indigenous People's Rights Act of 1997.

${ }^{99}$ For a journalistic account of the Diwalwal gold rush, see Gonzales and Conde 2002.

${ }^{100}$ Personal interviews, but see also Regelado 2000 and Gonzales and Conde 2002.
} 
In 2003, mounting tensions culminated in the assassination of the mayor, allegedly by elements connected with small-scale miners and the NPA. ${ }^{101}$ In addition, the enactment of the Indigenous People's Rights Act in 1997 sparked intense and even bloody competition over mining royalties between tribal groups that had started siding with mining investors and local politicians. ${ }^{102}$ In 2008 , in a blunt effort to restore peace and order in Diwalwal, the government of Gloria Macapagal-Arroyo (2001-2010) decided to nationalize the area by turning it into a mineral reservation and by sending in the armed forces, purportedly to rid the area of communist insurgents. ${ }^{103}$ In the end, subsequent national government interventions have largely failed to defuse tensions in Diwalwal, and the widely held sentiment among small-scale miners is that the beefed-up presence of military and police forces are furthering the interests of JB Mining and its large-scale mining peers. At several instances, state security forces have purportedly joined hands with JB Mining's security guards (the "black ninjas") to protect JB's tunnels or to disperse protesting small-scale miners. ${ }^{104}$

\section{Conclusion}

The entry point of this article was an empirical analysis of the anatomy of the local state on the eastern Mindanao mining frontier. Building on critical academic literature concerning the relationship between the informal mining economy and the state I have argued that, rather than being detrimental to state power, the expansion of informal small-scale gold mining in recent decades has paradoxically gone hand in hand with, and has been facilitated by, the consolidation of state rule in the purportedly unruly uplands. ${ }^{105}$ This parallel process of SSM expansion and state consolidation is epitomized by the emergence of "joint institutions of extraction"106 that serve the interests of an indistinct coalition of local miner-politicians and various "capital interests" 107 involved in small-scale mining. Even leaving aside their personal involvement in smallscale mining, local miner-politicians use the sector as a source of fiscal revenues and as a platform to assert their authority. At the same time, mining financiers and informal landowners benefit from the regulatory interventions these same politicians support, notably the provision of protection services and the legitimation and arguably even formalization of otherwise informal land- and mineral-tenure arrangements.

Transcending the locality, these joint extraction regimes at the local level are a constitutive part of a broader, historically rooted pact between local politicians and national-level elites whereby the former, in exchange for their prerogatives in the local informal mining economy, fulfill key roles as frontier "stabilizers" and as agents of democratic state rule. At the same time, I also drew attention to the threats posed by the expansion of large-scale mining, which is undermining existing joint extraction regimes in the informal mining economy, and upsetting sociopolitical stability in the process.

To be sure, the long-term effects of large-scale mining expansion on sociopolitical stability are as of yet undetermined, and much will depend on the inclusiveness of the new institutional arrangements accompanying this expansion. Local politicians - many of whom are known to have a stake in small-scale mining - are now trying to convince mining companies to come to

\footnotetext{
101“Compostela Valley Mayor ..." 2003.

${ }^{102}$ Interview with anonymous respondent, Davao City, February 2012.

${ }^{103}$ Regelado 2009.

${ }^{104}$ Gonzales and Conde 2002.

${ }^{105}$ Scott 2009.

${ }^{106}$ Snyder 2006.

${ }^{107}$ Verbrugge 2014.
} 
a solution that takes into account the interests of the different players that currently derive their wealth and power from small-scale mining. The provincial governor, in particular, is now trying to reconcile the interests of local SSM elites and mining companies, in what was widely referred to as a win-win solution. Yet mining companies seem reluctant to accept such a negotiated solution, opting instead for militarization, bringing in military, para-military and/or private security forces in an attempt to monopolize access to mineral resources. Furthermore, even if some of these mining companies eventually prove willing to toe the consensual line, the hoped-for win-win solution is unlikely to meet the needs of the tens of thousands that now depend on small-scale mining for their everyday survival. In the long term, both social justice and sociopolitical stability would be best served by solutions aimed at including local populations as a whole, rather than merely those individuals who command the necessary "policing power" to subdue local resistance to the entry of large-scale mining.

\section{Notes on contributor}

Boris Verbrugge is a PhD student and research fellow at Conflict Research Group, Ghent University. For his $\mathrm{PhD}$, he has done extensive field research in small-scale gold mining areas in the southern Philippines. Specific research interests include the relationship between informal mining and the state, historical processes of differentiation in the sector, and the precarious position of its informal workforce.

\section{References}

Abinales, Patricio N. 2000. Making Mindanao: Cotabato and Davao in the Formation of the Philippine Nation-State. Manila: Ateneo de Manila University Press.

Adam, Jeroen, and Boris Verbrugge. 2014. "Informal Conflict Management in Exclusivist Political Orders: Some Observations on Central Mindanao." Austrian Journal of South-East Asian Studies 7 (1): 61-74.

Ballentine, Karen, and Heiko Nitzschke, eds. 2003. Beyond Greed and Grievance: Policy Lessons from Studies in the Political Economy of Armed Conflict. Boulder: Lynne Rienner Publishers.

Benjaminsen, Tor, and Christian Lund, eds. 2003. Securing Land Rights in Africa. London: Frank Cass.

Bräutigam, Deborah, Odd-Helge Fjeldstad, and Mick Moore. 2008. Taxation and State-Building in Developing Countries: Capacity and Consent. Cambridge: Cambridge University Press.

Collier, Paul, and Anke Hoeffler. 2004. "Greed and Grievance in Civil War." Oxford Economic Papers 56 (4): 563-95.

"Compostela Mayor Third to Be Killed in a Week." 2003. The Philippine Daily Inquirer, June 30, A1, A18.

Cuvelier, Jeroen, Koen Vlassenroot, and Nathaniel Olin. 2013. "Resources, Conflict and Governance: A Critical Review of the Evidence.” JSRP Paper 9. Accessed 24 January, 2014. http://www.lse.ac.uk/ internationalDevelopment/research/JSRP/downloads/JSRP9.Cuvelier.Vlassenroot.Olin.pdf.

Di John, John. 2010. “Taxation, Resource Mobilization and State Performance.” Crisis States Working Paper Series 2 (84). Accessed 13 June, 2013. http://www.lse.ac.uk/internationalDevelopment/research/ crisisStates/download/wp/wpSeries2/WP842.pdf.

Duffield, Mark. 2001. Global Governance and the New Wars: The Merging of Development and Security. London: Zed Books.

Eaton, Kent. 2001. "Political Obstacles to Decentralization: Evidence from Argentina and the Philippines." Development and Change 32 (1): 101-127.

Eriksen, Stein S. 2011. "State Failure" in Theory and Practice: The Idea of the State and the Contradictions of State Formation." Review of International Studies 37 (1): 229-247.

Fisher, Eleanor. 2008. "Artisanal Gold Mining at the Margins of Mineral Resource Governance: A Case from Tanzania." Development Southern Africa 25 (2): 199-213.

Francisco, Rosemarie. 2012. "Special Report: Philippines' Black Market Is China's Golden Connection." Accessed 11 July, 2014. http://www.reuters.com/article/2012/08/23/us-philippines-gold-idUSBRE87M02 120120823.

Gonzales, Daisy C., and H. Carlos Conde. 2002. "Diwalwal's Never-Ending Tragedies." Accessed 13 June, 2013. http://bulatlat.com/news/2-30/2-30-caloy1.html. 
Gulane, Judy T. 2003. "Informal Land Markets and Conflict in Maguindanao." In Out of the Shadows: Violent Conflict and the Real Economy of Mindanao, edited by Francisco Lara and Steven Schoofs, 145-196. London: International Alert.

Hansen, Tobias B., and Finn Stepputat. 2001. States of Imagination: Ethnographic Explorations of the Postcolonial State. London: Duke University Press.

Hedman, Eva-Lotte, and John T. Sidel. 2000. Philippine Politics and Society in the Twentieth Century: Colonial Legacies, Post-Colonial Trajectories. London: Routledge.

Holden, William N. 2005. "Civil Society Opposition to Nonferrous Metals Mining in the Philippines." Social Change 16 (3): 223-249. doi:10.1007/s11266-005-7723-1.

Hutchcroft, Paul. 2000. "Colonial Masters, National Politicos, and Provincial Lords: Central Authority and Local Autonomy in the American Philippines, 1900-1913." The Journal of Asian Studies 59 (2): 277-306.

Jimeno, Jaileen F. 2009. “A Watchdog in Need of Watching.” Accessed 8 July, 2014. http://pcij.org/stories/ 2009/zambales4.html.

Kreuzer, Peter. 2009. "Private Political Violence and Boss-Rule in the Philippines." Behemoth 2 (1): 47-63.

Landé, Carl. H. 1968. "Parties and Politics in the Philippines." Asian Survey 8 (9): 725-747.

Lara, Francisco, and Steven Schoofs. 2013. Out of the Shadows: Violent Conflict and the Real Economy of Mindanao. London: International Alert.

Larsson, Tomas. 2013. "The Strong and the Weak: Ups and Downs of State Capacity in Southeast Asia." Asian Politics \& Policy 5 (3): 337-358.

La Viña, Tony, and Alaya De Leon. 2012. "Mining E.O. Not Perfect, But Very Good.” Accessed 29 July, 2014. http://www.rappler.com/thought-leaders/8385-mining-e-o-not-perfect,-but-very-good.

Le Billon, Philippe. 2001. "The Political Ecology of War: Natural Resources and Armed Conflicts." Political Geography 20 (5): 561-584.

Le Billon, Philippe. 2008. "Diamond Wars? Conflict Diamonds and Geographies of Resource Wars." Annals of the Association of American Geographers 98 (2): 345-372.

Levi, Margaret. 1988. Of Rule and Revenue. Berkeley: University of California Press.

Levi, Margaret, and Audrey Sacks. 2009. "Legitimating Beliefs: Sources and Indicators." Regulation and Governance 3 (4): 311-333.

Lund, Christian. 2006. "Twilight Institutions: Public Authority and Local Politics in Africa." Development and Change 37 (4): 685-705.

McCoy, Alfred W. 1994. An Anarchy of Families: State and Society in the Philippines. Madison: University of Wisconsin Press.

Meagher, Kate. 1995. "Crisis, Informalization and the Urban Informal Sector in Sub-Saharan Africa." Development and Change 26 (2): 259-284.

Nordstrom, Carolyn. 2000. "Shadows and Sovereigns." Theory, Culture and Society 17 (4): 35-54.

Nordstrom, Carolyn. 2004. Shadows of War: Violence, Power and International Profiteering in the 21st Century. Berkeley: University of California Press.

Pattenden, Jonathan. 2011. "Gatekeeping as Accumulation and Domination: Decentralization and Class Relations in Rural South India." Journal of Agrarian Change 11 (2): 164-194.

Regelado, Edith. 2000. "Rival Mining Firms in Diwalwal Clash, 15 Injured." Accessed 3 November, 2013. http://www.philstar.com/headlines/86812/rival-mining-firms-diwalwal-clash-15-injured.

Regelado, Edith. 2009. “AFP Strengthens Diwalwal Presence.” Accessed 5 April, 2014. http://www.philstar. com/nation/461879/afp-strengthens-diwalwal-presence.

Reno, William. 1995. Corruption and State Politics in Sierra Leone. Cambridge: Cambridge University Press.

Reno, William. 1999. Warlord Politics and African States. Boulder: Lynne Rienner Publishers.

Rubbers, Benjamin. 2007. "Retour sur le 'secteur informel': L'économie du Katanga (Congo-Zaïre) face à la falsification de la loi." Sociologie du Travail 49 (3): 316-329.

Scott, James C. 2009. The Art of Not Being Governed. New Haven: Yale University Press.

Sharma, Aradhana, and Akhil Gupta. 2006. The Anthropology of the State: A Reader. Oxford: Blackwell Publishing.

Sherman, Jake. 2003. "Burma, Lessons from the Cease-Fires." In Beyond Greed and Grievance: Policy Lessons from Studies in the Political Economy of Armed Conflict, edited by Karen Ballentine and Heiko Nitzschke, 225-255. Boulder: Lynne Rienner Publishers.

Sidel, John T. 1999. Capital, Coercion and Crime: Bossism in the Philippines. Stanford: Stanford University Press.

Sikor, Thomas, and Christian Lund. 2009. "Access and Property: A Question of Power and Authority." Development and Change 40 (1): 1-22. 
Snyder, Richard. 2006. "Does Lootable Wealth Breed Disorder? A Political Economy of Extraction Framework." Comparative Political Studies 39 (8): 943-968.

Tiu, Macario. 2005. Davao: Reconstructing History from Text and Memory. Davao: Ateneo de Davao University.

Trouillot, Michel-Rolph. 2001. "The Anthropology of the State in the Age of Globalization: Close Encounters of the Deceptive Kind." Current Anthropology 42 (1): 125-138.

Tsing, Anna L. 2003. "Natural Resources and Capitalist Frontiers." Economic and Political Weekly 38 (48): $5100-5106$.

Umehara, Hirumitsu, and Germelino M. Bautista. 2004. Communities at the Margins: Reflections on Philippine Economic, Environmental and Social Changes. Manila: Ateneo de Manila Press.

Usaid. 2011. "USAID Country Profile: Philippines - Property Rights and Resource Governance." Accessed 12 July, 2014. http://usaidlandtenure.net/sites/default/files/country-profiles/fullreports/USAID_Land_ Tenure_Philippines_Profile.pdf.

Verbrugge, Boris. 2014. "Capital Interests: A Historical Analysis of the Transformation of Small-Scale Gold Mining in Compostela Valley Province, Southern Philippines." The Extractive Industries and Society 1 (1): 86-95.

Vitug, Marites D. 1993. The Politics of Logging: Power from the Forest. Pasig City: Philippine Center for Investigative Journalism.

Vu, Tuong. 2010. "Studying the State through State Formation." World Politics 62 (1): 148-175.

Weiss, Linda. 1987. "Explaining the Underground Economy: State and Social Structure." The British Journal of Sociology 38 (2): 216-234.

Wernstedt, Frederik L., and Paul D. Simkins. 1965. "Migrations and the Settlement of Mindanao." The Journal of Asian Studies 25 (1): 83-103.

Wong, Pak N. 2006. "Outline of an Anthropology of the Modern Philippine State: Political Decentralization, Internal Pacification, and the Strongmen as State Builders." The Journal of Comparative Asian Development 5 (2): 247-277.

Wong, Pak N., Kathlene Aquino, Kristinne Lara-de Leon, and Sylvia Yuen Fun So. 2013. "As Wind, Thunder and Lightning: Local Resistance to China's Resource-Led Diplomacy in the Christian Philippines." South East Asia Research 21 (2): 281-302. 